\title{
Study of Conventional Bank Health in Indonesia from 2012 to 2017
}

\author{
Yusnita Octafilia*, Evelyn Wijaya \\ Management Department \\ Pelita Indonesia School of Business \\ Pekanbaru, Indonesia \\ *yoctafilia.pelitaindonesia@yahoo.com, evelynwijaya53@gmail.com
}

\begin{abstract}
Health bank level method that had been changed three times, from CAMEL, CAMELS to RGEC is Bank Indonesia's strategy in order to protect banking sector which is susceptive to economy crisis. It is attractive because RGEC method is just implemented in Indonesia's banking sector and it known from international researches that are still using CAMELS such as Vietnam, South Africa, India and Bangladesh. Then, the aim of this study is to analyze conventional health bank in Indonesia by combining CAMELS and RGEC methods; assets, rentability, liquidity, solvability and sensitivity of market risk. This study's object is conventional bank in Indonesia with $\mathbf{5 0}$ banks as sample and period of study is from 2012 to 2017 . The result of this study shows that assets ratio which is represented by Capital Adequacy Ratio and Net Interest Margin are mostly on 1 and 2 composite level. Rentability ratio which is represented by Return on Assets and Net Profit Margin are on 1 and 3 composite level, while Loan to Deposit Ratio and Net Performing Loan which represent liquidity ratio are mostly on composite level 1. Then, solvability ratio is represented by Operational Fee of Operational Income and sensitivity of market risk ratio is represented by Interest Rate Risk are on composite level 1 commonly. It means that conventional health bank in Indonesia from 2012 to 2017 is very healthy or adequate. From the result of this study is expected to be able to increase society's trust to banking sector then it can increase people investment in bank which is directly could support economy growth of Indonesia.
\end{abstract}

Keywords: banking health, conventional, CAMELS, RGEC

\section{INTRODUCTION}

Economy crisis in the mid 1997 affected all sectors including banking sector where there were many banks experience liquidity difficulties since rupiah exchange value which decreases. Indonesian banking sector experienced crisis again in 2008 where the interest rate was forcedly decreased so that the community consumption and investment increased. These two conditions indicate that bank is very susceptible towards massive withdrawal by customer. Assessment of banking soundness was conducted in the form of quantitative and qualitative assessment which was based on the bank condition or performance such as the factors of capital, asset quality, management earning, liquidity, and sensitivity to market risk, although the various table text styles are provided. Therefore, Bank Indonesia views that there is a need in perfecting the assessment method of bank soundness from
CAMELS into RGEC. CAMELS analysis stated in The Regulation of Bank Indonesia No. 6 [1], which includes Capital, Assets Quality, Management, Earning, Liquidity, Sensitivity to Market Risk added by Sensitivity to Market Risk due to the changes in banking activity in the last several years. So that CAMELS analysis becomes RGEC which is stated in The Regulation of Bank Indonesia No.13 and effective to be used since the first of January 2012, as well as includes Risk Profile, Good Corporate Governance, Earning and Capital [2].

The number of economy growth in Indonesia from 2010 to 2017 where in 2010 to 2015 tends to decrease. However, in the last three years, which is since 2015 to 2017, the amount of economy growth in Indonesia always experienced increased. This indicates that the development of Indonesia economy directs to the positive side. In the figure 2 , we can see that the growth of credit and third-party fund in Indonesia experiences increase about $1.3 \%$ to $12.7 \%$. Such growth indicates the development banking sector which is getting better.

Increasing of Indonesia economy is accompanied by the growth of credit and third-party fund which cannot be separated from banking sector since banking sector has a large role in managing the fund from the community. This condition also fives positive effect to the banking world in Indonesia so that the banking soundness becomes an important thing.

So, the number of economy growth and economy of Indonesia direct to positive side towards where the growth of conventional bank asset both State-Owned Commercial Bank and foreign exchange and non-foreign exchange of National Private Commercial Bank from 2012 to 2017 tends to increase. This means that the performance of conventional Bank in Indonesia improves.

Based on previous research, in general, the assessment of bank soundness still uses the CAMEL method (Capital, Asset, Management, Earning, Liquidity) or CAMELS (Capital, Asset, Management, Earning, Liquidity, Sensitivity to Market Risk), especially in the banking sector such as banks in Vietnam, South Africa, India and Bangladesh while Bank Indonesia has issued new regulations to assess the bank soundness using the RGEC (Risk Profile, GCG, Earning, Capital) method and there have been several previous studies examining the bank soundness rate using this method. Thus, the purpose of this 
Capital Adequacy Ratio (CAR) is the ratio used to indicate all risky assets originating from the bank's own capital in addition to funds originating from external parties. Capital Adequacy Ratio is calculated through:

\section{LITERATURE REVIEW}

Banking is all matters related to the bank both institutional, business activities, and the ways and processes implemented by banks in conducting their business. Banking in Indonesia adheres to the principle of economic democracy with the principle of prudence and has the main function as a collector and distributor of public funds. The purpose of Indonesian banking is to support the implementation of national development so that there will be an increase in development equity and results, economic growth and national stability towards improving the lives of many people. The strategic position of the banking system is to support the continuity of the operation of the payment system [3].

Bank is a business entity whose job is to collect those from the community in the form of savings and distribute to the public in the form of various forms of credit. There are 2 (two) types of banks which are Conventional Banks consisting of Conventional Commercial Bank and Rural Credit Bank and Sharia Bank consisting of Sharia Commercial Bank and Sharia People Financing Bank.

Conventional Bank is a bank that in its operational activities applies interest method and can obtain funds from outside parties in the form of demand deposits, deposit on call, transfer funds, shares and obligation. Conventional bank operational activities are done by producing various products that can raise public funds, channel funds that have been collected, and provide financial services [4]

Bank soundness rate assessment consists of (1) risk profile assessment which is an assessment of risks consisting of credit, market, operational, liquidity, legal, strategy, compliance, and reputation risks and the quality of the application of bank risk management, (2) assessment of Good Corporate Governance (GCG) factors which is done by using the principles of GCG including transparency, accountability, responsibility, independence and fairness, (3) assessment of profitability factors which is done by evaluating the performance, resources, sustainability, and earnings management both from quantitative and qualitative aspects, and (4) assessment capital factor which is done by evaluating the level of capital adequacy with the bank's risk profile and capital management because the higher the bank's risk, the greater the capital that must be provided to anticipate the risk [5].

This study employs an assessment of the bank soundness using 2 (two) methods: CAMELS and RGEC which are represented by five ratios, they are assets ratio, rentability, liquidity, solvability, and sensitivity of market risk. And these ratios represented by several ratios such as assets ratio is represented by Capital Adequacy Ratio and Net Interest Margin, rentability ratio is represented by Return on Assets and Net Profit Margin, Liquidity ratio is represented by Loan to Deposit Ratio and Net Performing Loan, Solvability ratio is represented by Operational Fee of Operational Revenue, and Sensitivity of Market Risk is represented by Interest Rate Risk.

The following is the description of each ratio:
CAPITAL

CAR $=$ WEIGHT ASSETS BASED ON RISK $\times 100 \%$

Net Interest Margin (NIM) is the ratio used to measure the ability of bank management to manage their assets with the aim of earning a net interest income. Therefore, the greater this ratio, the better the performance of banks in generating interest income so that the possibility of banks in problematic conditions will be smaller [6]. Net Interest Margin is calculated through:

$$
\mathrm{NIM}=\frac{\text { NET INTEREST INCOME }}{\text { PRODUCTIVE ASSETS MEAN }} \quad \mathrm{X} 100 \%
$$

Return on Assets (ROA) is a ratio that is useful for measuring the ability of banks to generate profits derived from investment activities [7]. Return on Assets is calculated through:

$$
\text { ROA }=\quad \frac{\text { PROFIT BEFORE TAX }}{\text { TOTAL ASSET MEAN }} \quad \text { X 100\% }
$$

Net Profit Margin (NPM) is the ratio that describes the level of bank profit against operating income. Therefore, the higher this ratio, the better the operational activities of the banks concerned. This ratio is measured using a formula of:

$$
\mathrm{NPM}=\quad \frac{\text { NET PROFIT }}{\text { OPERATIONAL INCOME }} \quad \mathrm{X} 100 \%
$$

Operational Fee of Operational Income (BOPO) is the ratio used to determine the level of efficiency and ability of banks to carry out operational activities. Operational Fee of Operational Income is calculated through:

$$
\mathrm{BOPO}=\frac{\text { OPERATIONAL EXPENSE }}{\text { OPERATIONAL INCOME }} \quad \mathrm{X} 100 \%
$$

Loan to Deposit Ratio (LDR) is the ratio used to measure the composition of the amount of credit given by banks compared to the amount of public funds and own capital used. Therefore, the higher this ratio, the lower the level of the bank liquidity concerned [8]. This ratio is measured using a formula of:

$$
\mathrm{LDR}=\frac{\text { AMOUNT OF CREDIT PROVIDED }}{\text { TOTAL OF THIRD PARTY FUND }} \quad \mathrm{X} 100 \%
$$

Net Performing Loan (NPL) is a ratio that shows the ability of bank management to manage problematic loans that have been given by banks as a result of customers not making payments so that it can reduce bank performance and cause banks to become inefficient. Therefore, the greater this ratio, the greater the credit risk faced by the bank concerned [9]. This ratio can be calculated using the following formula:

$$
\mathrm{NPL}=\quad \frac{\text { PROBLEM AT IC CREDIT }}{\text { TOTAL CREDIT }} \quad \mathrm{X} 100 \%
$$


Interest Rate Risk (IRR) is the ratio used to determine the interest rate, the exchange rate in circulation and the sensitivity of assets and liabilities to interest rates. Interest Rate Risk can be calculated using the following formula:

$$
I R R=\quad \frac{\text { RATE SENSITIVE ASSET }}{\text { RATE SENSITIVE LIABILITIES }} \quad \text { X 100\% }
$$

\section{METHOD}

The data in this study is secondary data where the source of data is from various documents in the form of books, journals, articles, annual reports and banking financial reports which are the object of research and other documents obtained from various media, including the internet.

This study employed purposive sampling data collection technique. Purposive sampling is a technique to determine the research samples based on certain considerations or criteria. The criteria used in this study are complete banking financial statements from 2012 to 2017.

The population used in this study is conventional banking companies that have financial statements from the period of 2012 to 2017 totaling 62 banks. Meanwhile, the banks that became the sample of this study amounted to 50 banks after being selected using several criteria.

The criteria used in determining the sample are (1) conventional banking companies with the 2012-2017 period, (2) banks that have complete financial statements for the period of 2012 to 2017.

\section{RESULTS AND DISCUSSION}

The following are the results of an assessment of the 50 conventional banks sampled in this study using the CAMELS method represented by CAR, NIM, ROA, NPM, BOPO, LDR, ROE and RGEC ratios represented by CAR, NIM, ROA, BOPO, NPL, GCG, IRR, and ROE rate in assessing the soundness of banks with the study period from 2012 to 2017.

TABLE I. CALCULATION OF CAPITAL ADEQUACY RATIO (CAR)

\begin{tabular}{|l|l|l|l|}
\hline \multicolumn{1}{|c|}{ Criteria } & Level & $\begin{array}{c}\text { Amount } \\
\text { of Bank }\end{array}$ & \multicolumn{1}{c|}{ Description } \\
\hline CAR $>15 \%$ & 1 & 46 & Very Health/Adequate \\
\hline $9 \% \leq \mathrm{CAR}<15 \%$ & 2 & 4 & Health/Adequate \\
\hline $8 \% \leq \mathrm{CAR}<9 \%$ & 3 & - & Pretty Health/Adequate \\
\hline $6 \%<\mathrm{CAR}<8 \%$ & 4 & - & Less Health/Adequate \\
\hline $\mathrm{CAR} \leq 6 \%$ & 5 & - & Un-Health/Adequate \\
\hline
\end{tabular}

Table I shows the Capital Adequacy Ratio (CAR) of conventional banks which is generally ranked 1 and there are 4 banks that are ranked 2. This means that all risk assets originating from the bank's own capital in addition to funds from external parties is in a healthy condition/adequate and healthy/ adequate where the high CAR value shows that the bank's condition is very good or adequate.
TABLE II. CALCULATION OF NET INTEREST MARGIN (NIM)

\begin{tabular}{|l|l|l|l|}
\hline \multicolumn{1}{|c|}{ Criteria } & Level & $\begin{array}{c}\text { Amount } \\
\text { of Bank }\end{array}$ & \multicolumn{1}{|c|}{ Description } \\
\hline NIM $>5 \%$ & 1 & 24 & Very Health/Adequate \\
\hline $2.01 \%<$ NIM $\leq 5 \%$ & 2 & 26 & Health/Adequate \\
\hline $1.5 \%<$ NIM $\leq 2 \%$ & 3 & - & Pretty Health/Adequate \\
\hline $0 \%<$ NIM $\leq 1.49 \%$ & 4 & - & Less Health/Adequate \\
\hline NIM $<0 \%$ & 5 & - & Un-Health/Adequate \\
\hline
\end{tabular}

Based on Table II, it can be seen that conventional banks have an average Net Interest Margin (NIM) at rank 1 and 2 which means that they are in very healthy/adequate and healthy/adequate conditions. The high value of Net Interest Margin (NIM) owned by banks shows that banks are in very good condition because banks have good bank management capabilities to manage their assets

TABLE III. CALCULATION OF RETURN ON ASSETS (ROA)

\begin{tabular}{|l|l|l|l|}
\hline \multicolumn{1}{|c|}{ Criteria } & Level & $\begin{array}{l}\text { Amount } \\
\text { of Bank }\end{array}$ & \multicolumn{1}{|c|}{ Description } \\
\hline ROA $>2 \%$ & 1 & 11 & Very Health/Adequate \\
\hline $1.26 \%<$ ROA $\leq 2 \%$ & 2 & 16 & Health/Adequate \\
\hline $\begin{array}{l}0.51 \%<\text { ROA } \leq \\
1.25 \%\end{array}$ & 3 & 15 & $\begin{array}{l}\text { Pretty } \\
\text { Health/Adequate }\end{array}$ \\
\hline $0 \%<$ ROA $\leq 0.5 \%$ & 4 & 4 & Less Health/Adequate \\
\hline ROA $<0 \%$ & 5 & 4 & Un-Health/Adequate \\
\hline
\end{tabular}

Return on Assets (ROA) of conventional bank which is shown in Table III shows generally in rank 1 - 3 although there are several banks which are ranked 4 and 5. This means that on average banks have a very healthy/adequate Return on Assets (ROA) - quite healthy/adequate where the higher the bank's rating, the better the performance of the bank concerned.

TABLE IV. CALCUlation OF NET PROFIT MARGIN (NPM)

\begin{tabular}{|l|l|l|l|}
\hline \multicolumn{1}{|c|}{ Criteria } & Level & $\begin{array}{c}\text { Amount } \\
\text { of Bank }\end{array}$ & \multicolumn{1}{|c|}{ Description } \\
\hline $\mathrm{NPM} \geq 100 \%$ & 1 & 1 & Very Health/Adequate \\
\hline $81 \% \leq \mathrm{NPM}<100 \%$ & 2 & 10 & Health/Adequate \\
\hline $66 \%<\mathrm{NPM}<81 \%$ & 3 & 32 & $\begin{array}{l}\text { Pretty } \\
\text { Health/Adequate }\end{array}$ \\
\hline $51 \%<\mathrm{NPM}<66 \%$ & 4 & 7 & Less Health/Adequate \\
\hline $\mathrm{NPM}<51 \%$ & 5 & - & Un-Health/Adequate \\
\hline
\end{tabular}

Based on Table IV, it can be seen that the Net Profit Margin (NPM) or the level of bank profit on operating income, on average is ranked 3, which is quite healthy. This means that the bank's operational activities are quite healthy where the higher the Net Profit Margin (NPM), the better its operational activities.

TABLE V. CALCULATION OF OPERATIONAL COST OF OPERATIONAL INCOME (BOPO)

\begin{tabular}{|l|l|l|l|}
\hline \multicolumn{1}{|c|}{ Criteria } & Level & $\begin{array}{c}\text { Amount } \\
\text { of Bank }\end{array}$ & \multicolumn{1}{|c|}{ Description } \\
\hline $83 \%<\mathrm{BOPO} \leq 88 \%$ & 1 & 23 & Very Health/Adequate \\
\hline $89 \%<\mathrm{BOPO} \leq 93 \%$ & 2 & 13 & Health/Adequate \\
\hline $94 \%<\mathrm{BOPO} \leq 96 \%$ & 3 & 3 & Pretty Health/Adequate \\
\hline $97 \%<\mathrm{BOPO} \leq 100 \%$ & 4 & 5 & Less Health/Adequate \\
\hline $\mathrm{BOPO}<100 \%$ & 5 & 6 & Un-Health/Adequate \\
\hline
\end{tabular}

In general, the operational costs of operational income (BOPO) of conventional bank shown in Table $\mathrm{V}$ are in ranks 1 
The ratio used in the CAMELS method to assess the health - 2 and there are several banks that are ranked 3 - 5. The lower the value of the Operational cost of Operational Income (BOPO) ratio, the more efficient and better ability of banks in carrying out operational activities.

TABLE VI. CALCULATION OF LOAN TO DEPOSIT RATION (LDR)

\begin{tabular}{|l|l|l|l|}
\hline \multicolumn{1}{|c|}{ Criteria } & Level & $\begin{array}{c}\text { Amount } \\
\text { of Bank }\end{array}$ & \multicolumn{1}{|c|}{ Description } \\
\hline $50 \%<\mathrm{LDR} \leq 75 \%$ & 1 & 6 & Very Health/Adequate \\
\hline $75 \%<\mathrm{LDR} \leq 85 \%$ & 2 & 13 & Health/Adequate \\
\hline $85 \%<\mathrm{LDR} \leq 100 \%$ & 3 & 28 & $\begin{array}{l}\text { Pretty } \\
\text { Health/Adequate }\end{array}$ \\
\hline $100 \%<\mathrm{LDR} \leq 120 \%$ & 4 & 1 & Less Health/Adequate \\
\hline LDR $>120 \%$ & 5 & 2 & Un-Health/Adequate \\
\hline
\end{tabular}

Loan to Deposit Ratio (LDR) of conventional banks shown in Table VI shows that they are generally ranked 3. This means that most banks have a healthy/adequate Loan to Deposit Ratio (LDR) where the more liquid a bank is, the better bank concerned.

TABLE VII. CALCULATION OF NET PERFORMING LOAN (NPL)

\begin{tabular}{|l|l|l|l|}
\hline \multicolumn{1}{|c|}{ Criteria } & Level & $\begin{array}{c}\text { Amount } \\
\text { of Bank }\end{array}$ & \multicolumn{1}{c|}{ Description } \\
\hline $0.25 \%<\mathrm{NPL} \leq 2 \%$ & 1 & 41 & Very Health/Adequate \\
\hline $2 \%<\mathrm{NPL} \leq 3.75 \%$ & 2 & 9 & Health/Adequate \\
\hline $3.75 \%<\mathrm{NPL} \leq 5 \%$ & 3 & - & Pretty Health/Adequate \\
\hline $5 \%<\mathrm{NPL} \leq 6.75 \%$ & 4 & - & Less Health/Adequate \\
\hline $\mathrm{NPL}<6.75 \%$ & 5 & - & Un-Health/Adequate \\
\hline
\end{tabular}

From Table VII, it can be seen that the average conventional bank has a Net Performing Loan (NPL) ranked 1 and 2 which means that it is in a strong and satisfying condition. This shows the lower the value of Net Performing Loans (NPL) owned by banks, the better the quality of bank credit will cause non-performing loans and the less likely the bank is in problem.

TABLE VIII. CALCULATION OF INTEREST RATE OF RISK (IRR)

\begin{tabular}{|l|l|l|l|}
\hline \multicolumn{1}{|c|}{ Criteria } & Level & $\begin{array}{c}\text { Amount } \\
\text { of Bank }\end{array}$ & \multicolumn{1}{|c|}{ Description } \\
\hline $45 \%<$ IRR & 1 & 49 & Strong \\
\hline $40 \%<\mathrm{IRR} \leq 45 \%$ & 2 & - & Satisfy \\
\hline $35 \%<\mathrm{IRR} \leq 40 \%$ & 3 & - & Pretty \\
\hline $30 \%<\mathrm{IRR} \leq 35 \%$ & 4 & - & Weak \\
\hline IRR $<30 \%$ & 5 & 1 & Inadequate \\
\hline
\end{tabular}

Table VIII shows that the conventional banks' Interest Rate of Risk (IRR) generally ranked 1 and there is 1 bank that is ranked 5. This means that banks already have a strong Interest Rate of Risk (IRR) where the higher the IRR value, the better the bank concerned.

\section{CONCLUSION}

Based on the analysis results of the bank soundness rating using the CAMELS and RGEC methods through five ratios in conventional banks for the 2012-2017 period, the following conclusions can be made: of conventional banks averaged at a composite rating of 1-3 where Capital Assets Ratio, Net Interest Margin, Operational Fee of Operational Revenue ratios tend to show very healthy conditions while the Return on Assets, Net Profit Margin, and Loan to Deposit Ratio conventional banks tend to show fairly healthy conditions.

RGEC method used to assess the soundness of conventional banks on average have a rating of 1-5 where the CAR, NIM, BOPO ratios tend to show very adequate conditions, NPL and IRR ratios tend to show strong conditions, ROA ratio tend to indicate quite adequate condition while the GCG ratio tends to indicate inadequate conditions.

Assessments of bank soundness using CAMELS and RGEC methods tend to be ranked 1-3. This means that the soundness of conventional banks in Indonesia is very healthy or very adequate to enough healthy or quite adequate. It shows that conventional bank in Indonesia already has good performance in pass six years which can describe the sustainability of conventional banks in every condition.

\section{IMPLICATION}

This study shows the results that can provide benefits for conventional banks in Indonesia, investors and other stakeholders, which is that there is still ROA, NPM, Operational Costs of Operational Income, LDR, and IRR of some conventional banks that are still in an unhealthy and even unhealthy condition. Based on these results, it is expected that banks can improve their strategy to be able to improve the composite of ROA, NPM, BOPO, LDR, and IRR so as to increase investor and community confidence in the bank concerned. So that third-party funds obtained by banks will increase as well.

\section{SUGGESTION}

This study uses CAMELS and RGEC methods to assess the soundness of banks represented only by CAR, NIM, ROA, NPM, BOPO, LDR, NPL, and IRR ratios which is not only conventional banks. It is expected that further studies can examine other ratios contained in the CAMELS and RGEC methods, For the banking sector, it is expected that banks that are not sampled in research can publish their annual reports so that they can become objects for further research. For banks that are the object of this research, can maintain their performance if it is ranked 1 and can improve its performance to be even better if it is ranked 2-5. For the community, it is expected that research can add knowledge and become input in investing.

\section{REFERENCES}

[1] The Regulation of Bank Indonesia No. 6/10/PBI/2004 dated on 12 April 2004

[2] The Regulation of Bank Indonesia No. 13/1/PBI/2011

[3] H. Chaniago and H. Widyantoro, "RBBR Model: A prediction model of bank health level based on risk for Regional Development Banks (BPD) in Indonesia," Journal of Economics, Business, and Accountancy Ventura vol. 20, no. 1, pp. 47-60,2017. 
[6] S. Riyadi, Banking Assets and Liability Management, Edisi Ketiga. Jakarta: Penerbit Fakultas Ekonomi Universitas Indonesia, 2009.

[4] N. Sunardi and L. Oktaviani, "Analisis Camel Dalam Menilai Tingkat Kesehatan Bank (Studi Kasus pada Subsektor Perbankan yang Terdaftar di BEI Periode 2011-2015),” Jurnal Ilmiah Ilmu Manajemen, INOVASI, 2016.

[5] K.S. Riadi, A.T. Atmadja, and M.A. Wahyuni,"Penilaian Tingkat Kesehatan Bank Dengan Menggunakan Metode RGEC (Risk Profile, Good Corporate Governance, Earnings, dan Capital) pada PT. Bank Mandiri (Persero), Tbk Periode 2013-2015," Jurnal Ilmiah Mahasiswa Akuntansi UNDIKSHA, vol 6, no. 3, 2016.

[7] Mardiyanto, Inti Sari Manajemen Keuangan. Jakarta: PT Gramedia Widiasarana Indonesia (GRASINDO), 2009

[8] Kasmir, Analisis Laporan Keuangan. Jakarta: Rajawali Pers, 2012.

[9] H. Darmawi, Manajemen Perbankan, Edisi Kedua. Padang: Bumi Aksara, 2012 